\title{
Biosorption of nickel (II) and zinc (II) from aqueous solutions by the biomass of yeast Yarrowia lipolytica
}

\author{
Sławomir Wierzba \\ University of Opole, Independent Department of Biotechnology and Molecular Biology, Kardynała Kominka 6a, 40-035 \\ Opole, Poland \\ "Corresponding author: e-mail: slawomirwierzba@uni.opole.pl
}

\begin{abstract}
This study examined the biosorption process of $\mathrm{Ni}(\mathrm{II})$ and $\mathrm{Zn}$ (II) from an aqueous solution by dead biomass of Yarrowia lipolytica. Optimum biosorption conditions were determined as a function of $\mathrm{pH}$, biomass dosage, contact time, and temperature. The biosorbent was characterized by FTIR, which indicated the participation of hydroxyl, carboxyl, amide and amine groups in the process of binding the metal ions. The results showed that the biosorption processes of both metal ions closely followed pseudo-second order kinetics. The equilibrium data of $\mathrm{Ni}(\mathrm{II})$ and $\mathrm{Zn}$ (II) ions at 20,30 and $40^{\circ} \mathrm{C}$ fitted the Langmuir and Freundlich isotherm models. Langmuir isotherm provided a better fit to the equilibrium data, with a maximum biosorption capacity of the $Y$. lipolytica biomass for $\mathrm{Ni}(\mathrm{II})$ and $\mathrm{Zn}$ (II) of 30.12 and $44.44 \mathrm{mg} / \mathrm{g}$ respectively. The calculated thermodynamic parameters demonstrated that the biosorption of $\mathrm{Ni}(\mathrm{II})$ and $\mathrm{Zn}(\mathrm{II})$ ions onto the Y. lipolytica was feasible, spontaneous and endothermic.
\end{abstract}

Keywords: biosorption, adsorption isotherms, zinc, nickel, Yarrowia lipolytica.

\section{INTRODUCTION}

Heavy metals constitute dangerous environmental pollution due to their high toxicity and tendency to migrate and bioaccumulate in the food chain. Zinc and nickel are metals prevalent in wastewater. Sources of zinc include industrial pollution from the production of batteries, paints, textiles, plastics, and from printing plants ${ }^{1}$. Excess levels of this metal cause disorders in the digestive tract, anemia, and impede the absorption of calcium, copper and iron. Zinc concentrations in drinking water should not exceed $5 \mathrm{mg} / \mathrm{l}^{2}$. Nickel is present in raw sewage of the galvanizing, paper, refining, metallurgical and fertilizer industries. Excess nickel levels accumulate in the lymph nodes, which may be the cause of many cancers. The content of nickel in drinking water should not exceed $0.02 \mathrm{mg} / \mathrm{l}^{3}$. The ever lower limits of heavy metal levels in water and wastewater discharged into the environment require new and efficient methods to remove them. Conventional methods of removing heavy metals from the environment include precipitation, ion exchange, coagulation, adsorption, flotation, reverse osmosis and electrochemical processes. The main disadvantages of these methods include the relatively low efficiency of treatment in wastewater with a low concentrations of metal ions. In addition, their use is energy-intensive and leads to large quantities of secondary impurities ${ }^{4}$. Alternative methods include biotechnological processes such as biosorption or bioaccumulation. They allow the use of cheaper and more efficient materials for sewage and wastewater with low concentrations of impurities (less than $100 \mathrm{mg} / \mathrm{l})^{5}$. The mechanism of binding biomass may take place by biosorption on the biosorbent's surface, bioaccumulation inside cells and chemical conversion of metal ions as a result of metabolic activity. Materials of biological origin are characterized by relatively large sorption capacities and are also much cheaper, especially when using waste materials from various industries (e.g. in food industry).

In recent years, Yarrowia lipolytica has been one of the most widely investigated unconventional yeast species, next to species such as Pichia pastoris, $P$. guilliermondii or Kluyveromyces lactis. Y. lipolytica strains are commonly found in nature and are frequently isolated from dairy products, for example cheeses or yogurt, meat products, e.g. sausages and environments rich in fats ${ }^{6}$. These microorganisms are strictly aerobic and have the capacity to be used as a carbon source in a wide variety of substrates (carbohydrates, alcohols, organic acids, alkanes, fatty acids and triglycerides). Physiological and biochemical properties, including the high secretory capability exhibited by $Y$. lipolytica, provided a basis for the biotechnological use of these microorganisms in biosynthesis, biotransformation and biodegradation. Currently, $Y$. lipolytica is used in the synthesis of organic acids, sweeteners, carotenoids, oil and microbiological protein ${ }^{7}$. Due to the high production of a number of enzymes, $Y$. lipolytica is a valuable tool in environmental protection - bioremediation of soil and water contaminated with oil, detoxification of aromatic compounds, biosorption of heavy metals and the treatment of wastewater from the fishing, oil and food industries ${ }^{3,7,8}$. The aim of this study was to evaluate the effectiveness of Y. lipolytica in removing $\mathrm{Ni}(\mathrm{II})$ and $\mathrm{Zn}$ (II) from aqueous solutions, to determine the mechanisms of ion binding, to determine the kinetics and equilibrium biosorption process, and the influence of process parameters on performance.

\section{EXPERIMENTAL MICROORGANISM AND PREPA- RATION OF BIOMASS}

Yarrowia lipolytica was sourced from the collection at the Independent Department of Biotechnology and Molecular Biology at the University of Opole, and was stored in YPD medium (2\% glucose, $1 \%$ yeast extract, $1 \%$ peptone, $2 \%$ agar, $\mathrm{pH} 6.0$ ) at $4^{\circ} \mathrm{C}$. For the purposes of biosorption determination, $Y$. lipolytica biomass was grown in a $500 \mathrm{ml}$ Erlenmeyer flask containing $100 \mathrm{ml}$ of liquid medium composed of $2 \%$ glucose, $1 \%$ yeast extract, $1 \%$ peptone, and $0.05 \% \mathrm{MgSO}_{4}(\mathrm{pH} 6.0)$. The culture was then incubated in a thermo-shaker at 120 $\mathrm{rpm}$ for 48 hours at $30^{\circ} \mathrm{C}$. The yeast cells were harvested 
in a stationary growth phase by centrifuging at $5000 \mathrm{rpm}$ for 10 minutes at $4^{\circ} \mathrm{C}$. The thus obtained biomass was washed three times with deionized water and dried at $80^{\circ} \mathrm{C}$ for $24 \mathrm{~h}$. The dried biomass of $Y$. lipolytica was pulverized in a mortar and used in the experiments on $\mathrm{Ni}(\mathrm{II})$ and $\mathrm{Zn}(\mathrm{II})$.

\section{Preparation of metal solutions}

The solutions of $\mathrm{Ni}(\mathrm{II})$ and $\mathrm{Zn}(\mathrm{II})$ at concentrations of $1000 \mathrm{mg} / \mathrm{l}$ were prepared by dissolving appropriate amounts of $\mathrm{NiCl}_{2} \cdot 6 \mathrm{H}_{2} \mathrm{O}$ and $\mathrm{ZnSO}_{4} \cdot 7 \mathrm{H}_{2} \mathrm{O}$ in deionized water. Other metal ion concentrations were achieved by further diluting the solutions with deionized water. The $\mathrm{pH}$ of the metal solutions was determined using $0.1 \mathrm{M}$ $\mathrm{NaOH}$ and $0.1 \mathrm{M} \mathrm{HCl}$. Freshly diluted solutions were used for each experiment. All chemicals used were of analytical grade.

\section{FTIR spectroscopy}

To identify potential functional groups and the possible binding sites related to $\mathrm{Ni}(\mathrm{II})$ and $\mathrm{Zn}(\mathrm{II})$ absorption, IR analysis was performed with a FTIR spectrometer (Fourier transform-infrared spectrometer, Nicolet Nexus, USA Nicolet Co.) One milligram (dry weight) of $Y$. lipolytica cells was mixed and ground with $100 \mathrm{mg}$ of $\mathrm{KBr}$ (Spectral) in an agate mortar. The IR spectra obtained at $400-4000 \mathrm{~cm}^{-1}$ were used to examine the biomass before and after metal-loading (for $24 \mathrm{~h}$ in 50 $\mathrm{mg} / \mathrm{l}$ initial $\mathrm{Ni}(\mathrm{II})$ and $\mathrm{Zn}(\mathrm{II})$ concentration).

\section{Biosorption experiments}

In the biosorption experiments we investigated the effects of $\mathrm{pH}$, quantity of biomass, contact time, initial metal ion concentration and temperature on the biosorption of $\mathrm{Ni}(\mathrm{II})$ and $\mathrm{Zn}(\mathrm{II})$ by Y. lipolytica. All experiments were performed in $250 \mathrm{ml}$ Erlenmeyer flasks containing $50 \mathrm{ml}$ of a solution of known $\mathrm{Ni}$ (II) or $\mathrm{Zn}$ (II) ion concentration in a thermo-shaker at $120 \mathrm{rpm}$. The effects of $\mathrm{pH}$ ranging from 3 to 8 were tested in solutions at an initial concentration of metal ions of $100 \mathrm{mg} / \mathrm{l}$ at $30^{\circ} \mathrm{C}$ for 60 minutes using $2 \mathrm{~g} / \mathrm{l}$ of biomass. The effect of the dose of yeast from 0.5 to $3 \mathrm{~g} / \mathrm{l}$ was determined under similar conditions at pH 5 and 6. The kinetics of the biosorption of $\mathrm{Ni}(\mathrm{II})$ and $\mathrm{Zn}(\mathrm{II})$ by $Y$. lipolytica were tested at 20, 30 and $40^{\circ} \mathrm{C}$ for various contact times in the range 10 to 180 minutes in solutions with an initial $100 \mathrm{mg} / \mathrm{l}$ concentration of ions, at a biomass dose of $2 \mathrm{~g} / \mathrm{l}$ and $\mathrm{pH}$ of 5 and 6 . Biosorption tests of nickel and zinc ions under equilibrium (adsorption isotherm) carried out at temperatures of 20,30 and $40^{\circ} \mathrm{C}$, in concentrations of metal ions ranging from 10 to $300 \mathrm{mg} / \mathrm{l}$ for 60 minutes, biomass dose of $2 \mathrm{~g} / \mathrm{l}$, and $\mathrm{pH}$ of 5 and 6 .

Metal ion concentrations in the experiments were determined spectrophotometrically using biosorption cuvette tests Spectroquant ${ }^{\circledR}$ Nickel Cell Test and Spectroquant ${ }^{\circledR}$ Zinc Cell Test (Merck, Germany). Prior to testing the samples were filtered with Whatman filter partitioning membranes (pore size $0.45 \mu \mathrm{m}$ ), diluted with deionized water to the measured range. The test cuvette was measured using a Photolab Spectral spectrophotometer (WTW, Germany).
The amount of adsorbed heavy metal ions per unit biosorbent ( $\mathrm{mg}$ metal ion/g dry biosorbent) was obtained by using the following expression:

$q_{e}=\frac{\left(C_{0}-C_{e}\right) V}{M}$

where $q_{e}$ is the amount of heavy metal adsorbed onto the unit amount of the biomass $(\mathrm{mg} / \mathrm{g}) ; C_{o}$ and $C_{e}$ are the concentrations of the heavy metals in the initial and equilibrium solution ( $\mathrm{mg} / \mathrm{l})$, and after biosorbtion, respectively, $V$ is the volume of the aqueous phase (1) and $M$ is the amount of the biomass $(\mathrm{g})$.

\section{Biosorption kinetics}

In order to clarify the kinetics of biosorption of $\mathrm{Ni}(\mathrm{II})$ and $\mathrm{Zn}$ (II) by the biomass of Y. lipolytica, the experimental data have been described using the most popular kinetic models, i.e. the pseudo-first order, pseudo-second order, as well as intraparticle diffusion.

The equation of Lagergren's pseudo-first order' ${ }^{9}$ after integration takes a rectilinear form:

$\ln \left(q_{e}-q_{t}\right)=\ln q_{e}-\frac{k_{1}}{2,303} t$

where $q_{e}$ and $q_{t}(\mathrm{mg} / \mathrm{g})$ are the amounts of metal ions sorbed at equilibrium time $(\mathrm{mg} / \mathrm{g})$ and $t(\mathrm{~min})$, respectively, and $k_{1}$ is the rate constant of the equation $(1 / \mathrm{min})$. The sorption rate constants $\left(k_{1}\right)$ can be determined experimentally by plotting $\ln \left(q_{e}-q_{t}\right)$ vs. $t$.

The sorption data were also analyzed in terms of a pseudo-second order mechanism proposed by Ho and McKay ${ }^{10}$. This model is based on the assumption that the adsorption follows second order chemisorptions and predicts the behavior over the whole range of concentration, and is in agreement with an adsorption mechanism being the rate controlling step ${ }^{\mathbf{1}}$.

The pseudo-second order model can be expressed as:

$\frac{t}{q_{t}}=\frac{1}{k_{2} q_{e}^{2}}+\frac{1}{q_{e}}$

where $k_{2}(\mathrm{~g} / \mathrm{mg} \cdot \mathrm{min})$ is the rate constant of the second-order equation, $q_{t}(\mathrm{mg} / \mathrm{g})$ is the amount of biosorption time $t(\mathrm{~min})$ and $q_{e}$ is the amount of biosorption equilibrium $(\mathrm{mg} / \mathrm{g})$.

The initial sorption rate is ${ }^{11}$ :

$h=k_{2} q_{e}^{2}$

The slopes and intercepts of plots versus were used to calculate the second-order rate constants $k_{2}$ and $q_{e}$.

In order to examine the mechanism of $\mathrm{Ni}$ (II) and $\mathrm{Zn}$ (II) biosorption by the biomass of $Y$. lipolytica the intraparticle diffusion model of Weber and Morris was used ${ }^{\mathbf{1 2}}$ : $q_{t}=k_{i d} t^{0.5}+C_{i d}$

where $q_{t}(\mathrm{mg} / \mathrm{g})$ is the amount adsorbed at time $t$ ( $\mathrm{min}$ ) and $k_{i d}\left(\mathrm{mg} / \mathrm{g} \cdot \mathrm{min}^{0.5}\right)$ is the rate constant of intraparticle diffusion. $C_{i d}$ is the value of intercept which gives an idea about the boundary layer thickness, i.e. the larger the intercept, the greater the boundary effect.

Finally, it is possible to determine the sorption energy by fitting the kinetic constant $\left(k_{2}\right)$ from the pseudo-second order model at different temperatures to the Arrhenius equation ${ }^{\mathbf{1 3}}$ : 
$k_{2}=k_{o} \cdot \exp \left(\frac{-E_{A}}{R T}\right)$

where $k_{\mathrm{o}}$ is the temperature independent factor in $(\mathrm{g} / \mathrm{mg} \cdot \mathrm{min}), E_{A}$ is the activation energy of biosorption in $(\mathrm{kJ} / \mathrm{mol}), R$ is the gas constant $(8.314 \mathrm{~J} / \mathrm{mol} \cdot \mathrm{K})$ and $T$ is the solution temperature in $(\mathrm{K})$.

\section{Biosorption isotherm models}

The description of the equilibrium of $\mathrm{Ni}(\mathrm{II})$ and $\mathrm{Zn}(\mathrm{II})$ biosorption by Y. lipolytica was based on the Langmuir ${ }^{14}$ and Freundlich ${ }^{15}$ models. The Langmuir model represents one of the first theoretical treatments of nonlinear sorption and suggests that uptake occurs on a homogeneous surface by monolayer sorption without interaction between the adsorbed molecules. In addition, this model assumes uniform energies of adsorption onto the surface and no transmigration of the adsorbate ${ }^{\mathbf{1 1}}$. The Langmuir isotherm is represented in the following equation:

$q_{e}=\frac{q_{\max } K_{L} C_{e}}{1+K_{L} C_{e}}$

where $q_{e}$ is the equilibrium metal ion concentration on the sorbent $(\mathrm{mg} / \mathrm{g}), C_{e}$ is the equilibrium metal ion concentration in the solution $(\mathrm{mg} / \mathrm{l}), q_{\max }$ is the monolayer sorption capacity of the sorbent $(\mathrm{mg} / \mathrm{g}), K_{L}$ and is the Langmuir sorption constant $(1 / \mathrm{mg})$ related to the free energy of sorption. Eq. (7) is usually linearized to obtain the following from:

$\frac{C_{e}}{q_{e}}=\frac{C_{e}}{q_{\max }}+\frac{1}{K_{L} q_{\max }}$

The essential characteristic of the Langmuir isotherm can be expressed in terms of dimension less constant separation factor for equilibrium parameter $R_{L}$, which is defined by ${ }^{16}$ :

$R_{L}=\frac{1}{1+K_{L} C_{o}}$

where $C_{o}$ is the highest $\mathrm{Ni}(\mathrm{II})$ and $\mathrm{Zn}(\mathrm{II})$ concentration $(\mathrm{mg} / \mathrm{l})$.

The Freundlich isotherm is a nonlinear sorption model. This model proposes a monolayer sorption with a heterogeneous energetic distribution of active sites, accompanied by interactions between adsorbed molecules. The general form of this model is:

$q_{e}=K_{F} C_{e}^{\frac{1}{n}}$

where $K_{F}$ is a constant relating the biosorption capacity and $\frac{1}{n}$ is an empirical parameter relating the biosorption intensity, which varies with the heterogeneity of the material. The logarithmic form of Eq. (10) is:

$\ln q_{e}=\ln K_{F}+\frac{1}{n} \ln C_{e}$

\section{Thermodynamic parameters}

In order to describe the thermodynamic behaviour of the biosorption of $\mathrm{Ni}(\mathrm{II})$ and $\mathrm{Zn}$ (II) ions onto Y. lipolytica biomass, thermodynamic parameters including the change in free energy $\left(\Delta G_{o}\right)$, enthalpy $\left(\Delta H_{o}\right)$ and entropy $\left(\Delta S_{o}\right)$ were calculated from the following equations:

$\Delta G^{o}=-R T \cdot \ln K_{c}^{o}$ where $R$ is the universal gas constant $(8.314 \mathrm{~J} / \mathrm{mol} \cdot \mathrm{K})$ and $T$ is temperature $(\mathrm{K}), K_{c}^{o}$ is the equilibrium constant obtained from the Langmuir isotherm. The free energy change indicates the degree of spontaneity of the biosorption process, and a higher negative value reflects more energetically favorable adsorption ${ }^{13}$.

The apparent equilibrium constant of the biosorption is defined as:

$K_{c}^{o}=\frac{C_{a}}{C_{e}}$

where $C_{a}$ is the amount of $\mathrm{Ni}(\mathrm{II})$ or $\mathrm{Zn}(\mathrm{II})(\mathrm{mg})$ adsorbed onto the biosorbent per litre of solution at equilibrium and $C_{e}$ is the residual metal ion concentration at equilibrium in the solution $(\mathrm{mg} / \mathrm{l})$. The equilibrium constant may be expressed in terms of enthalpy change of biosorption $\left(\Delta H^{\circ}\right)$ and entropy change of biosorption $\left(\Delta S^{o}\right)$ as a function of temperature ${ }^{4}$ :

$\ln K_{c}^{o}=\frac{\Delta S^{o}}{R}-\frac{\Delta H^{o}}{R T}$

\section{Data analysis}

All the experiments were carried out in triplicates and the values reported as mean \pm SD. SigmaPlot ${ }^{\circledR}$ was used to fit the kinetics and equilibrium models using nonlinear regression.

\section{RESULTS AND DISCUSSION}

\section{FTIR analysis}

FTIR analysis was performed to give a qualitative and preliminary analysis of the main functional groups present on the cell wall which may be responsible for $\mathrm{Ni}(\mathrm{II})$ and $\mathrm{Zn}$ (II) biosorption (Fig. 1).

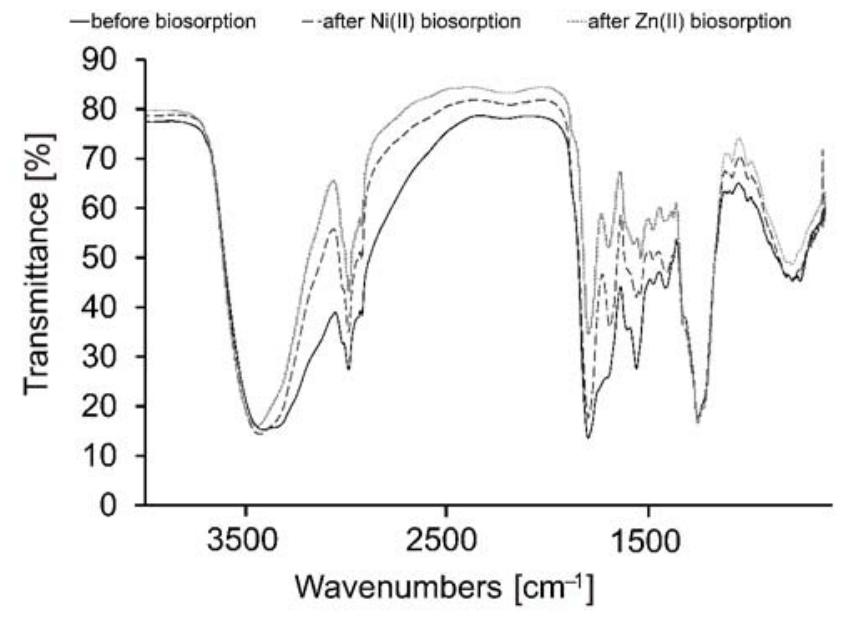

Figure 1. FTIR spectra of. Y. lipolytica before and after Ni(II) and $\mathrm{Zn}(\mathrm{II})$ biosorption

Fourier transform infrared (FTIR) spectra indicated the presence of hydroxyl, carboxylic, amido and amino groups which are important sites for metal biosorption (Table 1).

The position of the absorption bands in the FTIR spectra is related to the change in energy of particles resulting from the stretching and bending vibration of the atoms. A change within the range of absorption bands of certain functional groups, resulting from the adsorption of $\mathrm{Ni}(\mathrm{II})$ and $\mathrm{Zn}(\mathrm{II})$ on the surface of $Y$. lipolytica cells, 
Table 1. FTIR spectra characteristics of Y. lipolytica biomass before and after treatment with heavy metals

\begin{tabular}{|c|c|c|c|c|c|c|c|}
\hline \multirow{2}{*}{$\begin{array}{l}\text { Wavelength } \\
\text { range }\left[\mathrm{cm}^{-1}\right]\end{array}$} & \multicolumn{5}{|c|}{ Y. lipolytica biomass $\left[\mathrm{cm}^{-1}\right]$} & \multirow[t]{2}{*}{ Bond } & \multirow{2}{*}{$\begin{array}{l}\text { Functional } \\
\text { group }\end{array}$} \\
\hline & $\begin{array}{l}\text { Before } \\
\text { sorption }\end{array}$ & $\begin{array}{c}\text { After } \\
\text { sorption } \\
\text { of } \mathrm{Ni}(\mathrm{II})\end{array}$ & Differences & $\begin{array}{c}\text { After } \\
\text { sorption } \\
\text { of } Z n(I I)\end{array}$ & Differences & & \\
\hline $3600-3200$ & 3376 & 3395 & +19 & 3411 & +35 & $\begin{array}{c}\mathrm{O}-\mathrm{H} \text { stretching } \\
\mathrm{H} \text {-bonded }\end{array}$ & Hydroxyl \\
\hline $3100-2800$ & 2925 & 2924 & -1 & 2923 & -2 & $\mathrm{C}-\mathrm{H}$ stretching & Alkanes \\
\hline $\begin{array}{l}1690-1640 \\
1860-1620\end{array}$ & 1657 & 1655 & -2 & 1654 & -3 & $\begin{array}{l}\mathrm{C}=\mathrm{O} \text { stretching } \\
\mathrm{C}=\mathrm{C} \text { stretching }\end{array}$ & $\begin{array}{l}\text { Amides } \\
\text { alkenes }\end{array}$ \\
\hline $1560-1515$ & 1553 & 1541 & -12 & 1549 & -4 & C-N stretching & Amides \\
\hline $1480-1350$ & 1400 & 1402 & +2 & 1415 & +15 & $\mathrm{C}-\mathrm{H}$ bending & Alkanes \\
\hline $1320-1210$ & 1311 & 1308 & -3 & 1316 & +5 & C-O stretching & $\begin{array}{l}\text { Carboxyl } \\
\text { acids }\end{array}$ \\
\hline $\begin{array}{l}1320-1210 \\
1360-1080\end{array}$ & 1247 & 1241 & -6 & 1252 & +5 & C-O stretching & $\begin{array}{l}\text { Carboxyl } \\
\text { acids }\end{array}$ \\
\hline $\begin{array}{l}1360-1080 \\
1050-1150\end{array}$ & 1075 & 1072 & -3 & 1072 & -3 & $\begin{array}{l}\mathrm{C}-\mathrm{O} \text { stretching } \\
\mathrm{C}-\mathrm{N} \text { stretching }\end{array}$ & $\begin{array}{l}\text { Alcohols } \\
\text { amines }\end{array}$ \\
\hline
\end{tabular}

suggests that these groups are responsible for binding metal ions. A broad band of $3376 \mathrm{~cm}^{-1}$ is indicative of the stretching vibration of the hydroxyl groups of alcohols and carboxylic acids ${ }^{\mathbf{1 3}}$. Band shifts after the biosorption process suggest a significant role of the hydroxyl groups in the adsorption of $\mathrm{Ni}(\mathrm{II})$ (change +19 ) and $\mathrm{Zn}(\mathrm{II})$ (change +35 ) on the biosorbent's surface. Strong stretching and bending vibration in the range of 1400 $\mathrm{cm}^{-1}$ to $1657 \mathrm{~cm}^{-1}$ are characteristic for the presence of $\mathrm{C}=\mathrm{O}$ and $\mathrm{N}-\mathrm{H}$ bonds in the amide group of the protein. Significant band shifts on the surface of the yeast cells after biosorption, from 1553 to $1541 \mathrm{~cm}^{-1}(-12)$, and from 1400 to $1415 \mathrm{~cm}^{-1}(+15)$, indicate that the amide groups of proteins are highly involved in the adsorption of metal ions. The shifts from 1308 to $1316 \mathrm{~cm}^{-1}$ and from 1241 to $1252 \mathrm{~cm}^{-1}$ indicate stretching vibrations of C-O bonds due to carboxyl groups and may be responsible for electrostatic interactions between positive nickel and zinc ions and the negatively charged carboxylic groups. The shift between 1072 and $1075 \mathrm{~cm}^{-1}$ is indicative of stretching vibration of $\mathrm{C}-\mathrm{O}$ bonds from alcohols and carboxylic acids and $\mathrm{C}-\mathrm{N}$ bonds from amines.

The transmittance of the peaks in the loaded biomass was substantially lower than those in the raw sample of the yeast biomass. This indicates that bond stretching occurs to a lesser degree due to the presence of $\mathrm{Ni}$ (II) and $\mathrm{Zn}(\mathrm{II})$, and the following peak transmittance is reduced. These results are consistent with the study of Yin et al. ${ }^{17}$ and Ahmad et al. ${ }^{18}$ who observed that the biosorption of zinc and nickel ions by the biomass of yeast caused a decrease in transmittance compared to the control.

FTIR spectra of the $Y$. lipolytica biomass implicate hydroxyl, carboxyl, amide and amine groups in the biosorption of $\mathrm{Ni}(\mathrm{II})$ and $\mathrm{Zn}(\mathrm{II})$. Ahmad et al. ${ }^{18}$ showed that the biosorption process of $\mathrm{Zn}$ (II) by the biomass of Candida utilis and C. tropicalis involved hydroxyl, carboxyl, amide and amino groups. Similarly, Shinde et al. ${ }^{3}$ observed the participation of hydroxyl, carboxyl, carbonyl and amine groups in the biosorption of $\mathrm{Ni}(\mathrm{II})$ by $Y$. lipolytica. Also Asfaram et al. ${ }^{19}$ indicated the involvement of the hydroxyl, carboxyl, carbonyl, and amino groups in the biosorption of $\mathrm{Ni}(\mathrm{II}), \mathrm{Zn}(\mathrm{II})$, and $\mathrm{Co}(\mathrm{II})$ by Y. lipolytica ISF7. The authors also found that nickel ions bound via coordinate bonds with functional groups (amino and carboxyl groups) on the cellular walls of the yeast cells forming complexes. Such complexation is likely the mechanism behind the biosorption of nickel and zinc ions by $Y$. lipolytica.

\section{Effect of initial solution $\mathbf{p H}$}

The $\mathrm{pH}$ of the solution was one of the most important parameters affecting the efficiency of the biosorption of metal ions from the aqueous solutions. It is directly related with the competition ability of hydrogen ions with metal ions for active sites on the biosorbent surface ${ }^{\mathbf{2 0}, \mathbf{2 1}}$. Generally, metal biosorption involves complex mechanisms of ion exchange, chelation, adsorption by physical forces, and ion entrapment in inter and intra fibrillar capillaries and spaces of the cell structural network of a biosorbent ${ }^{22}$. FTIR analysis showed that $Y$. lipolytica has many functional groups such as hydroxyl, carboxyl, amide or amino groups involved in potential mechanisms of metal ion binding. Moreover, depending on the $\mathrm{pH}$ values of the aqueous solutions these functional groups participated in metal ion bindings. The effect of initial $\mathrm{pH}$ on $\mathrm{Ni}(\mathrm{II})$ and $\mathrm{Zn}(\mathrm{II})$ ion uptake capacity of $Y$. lipolytica was investigated between pH 2-8 at $100 \mathrm{mg} / \mathrm{l}$ initial metal ion concentration and a temperature of $30^{\circ} \mathrm{C}$. The results are shown in Figure 2. The maximum biosorption of nickel ions and zinc at 14.88 and $17.19 \mathrm{mg} / \mathrm{g}$ respectively were observed at pH 6 and 5. Similar results were obtained by Li et al. ${ }^{23}$, Liu et al. ${ }^{21}$ and Pahlavanzadeh et al. $^{24}$ Therefore, the remaining biosorption experiments were carried out at those $\mathrm{pH}$ values.

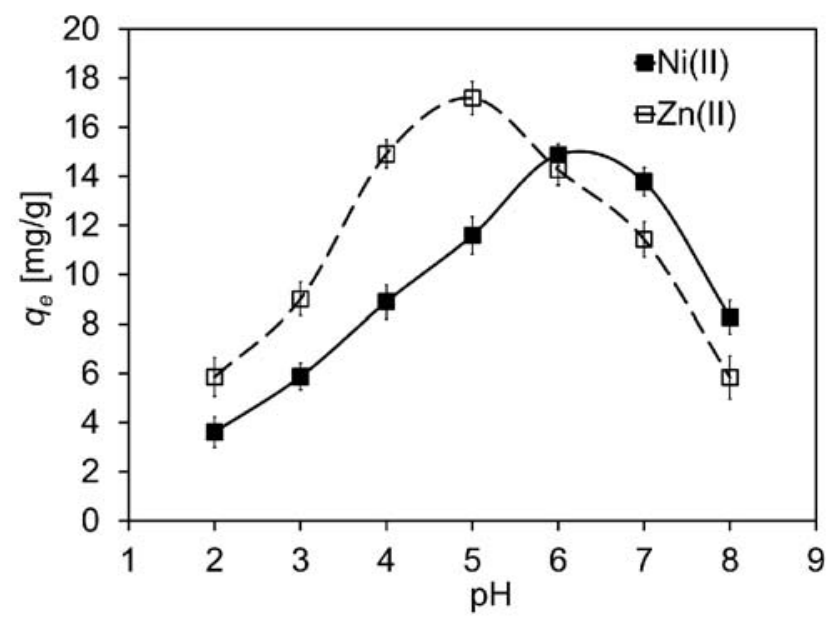

Figure 2. Effect of $\mathrm{pH}$ on the biosorption of $\mathrm{Ni}(\mathrm{II})$ and $\mathrm{Zn}(\mathrm{II})$ onto Y. lipolytica biomass (metal concentration: 100 $\mathrm{mg} / \mathrm{l}$, biomass dosage: $2 \mathrm{~g} / \mathrm{l}$, temperature: $30^{\circ} \mathrm{C}$ ) 
The biosorption mechanisms on the yeast cells surface reflect the nature of the physicochemical interaction of the solution. At a highly acidic $\mathrm{pH}$, the overall surface charge on the active sites became positive and metal cations and protons competed for binding sites on the cell wall, resulting in a lower uptake of metal ${ }^{25}$. As the biosorbent surface became more negatively charged as the $\mathrm{pH}$ solution increased from 2 to 5 , the functional groups of Y. lipolytica cells were more deprotonated and thus available for the metal ions. Li et al. ${ }^{23}$ and Özer and $\mathrm{Ozer}^{22}$ reported that as the $\mathrm{pH}$ increased to 5, more functional groups with negative charge such as carboxyl, amine or hydroxyl became exposed with a subsequent increase in attraction sites to positively charged ions, and thus enhanced the biosorption capacity. At a low $\mathrm{pH}$, cell wall ligands were closely associated with hydronium ions $\mathrm{H}_{3} \mathrm{O}^{+}$and restricted the approach of metal cations as a result of the repulsive force ${ }^{3}$. A decrease in biosorption yield at a higher $\mathrm{pH}(\mathrm{pH}>6)$ is related to the formation of soluble hydroxylated complexes of metal ions (nickel ions in the form of $\mathrm{Ni}(\mathrm{OH})_{2}$, zinc ions in the form of $\left.\mathrm{Zn}(\mathrm{OH})_{2}\right)^{23}$. Similar conclusions were presented by many authors conducting research on the biosorption of nickel and zinc ions using different biosorbents ${ }^{20,22,25}$.

\section{Effect of biosorbent dose on biosorption}

The study, in line with Munagapati et al. ${ }^{25}$ and Subbaiah and Yun ${ }^{26}$, indicates that the dose of biosorbent is also an important parameter influencing the sorption capacity and the efficiency of metal ion removal from the aqueous solution. The effect of the concentration of $Y$. lipolytica cells in the range of $0.5-3.0 \mathrm{~g} / \mathrm{l}$, the sorption capacity of the biomass and the percentage removal of $\mathrm{Ni}(\mathrm{II})$ and $\mathrm{Zn}$ (II) from the solution, are shown in Figure 3. The maximum biosorption of $\mathrm{Ni}(\mathrm{II})$ and $\mathrm{Zn}(\mathrm{II})$ was observed at a dose of $0.5 \mathrm{~g} / \mathrm{l}, 37.23$ and $42.04 \mathrm{mg} / \mathrm{g}$ respectively, while the percentage removal of metal ions from the solution was $39.96 \%$ and $48.04 \%$.

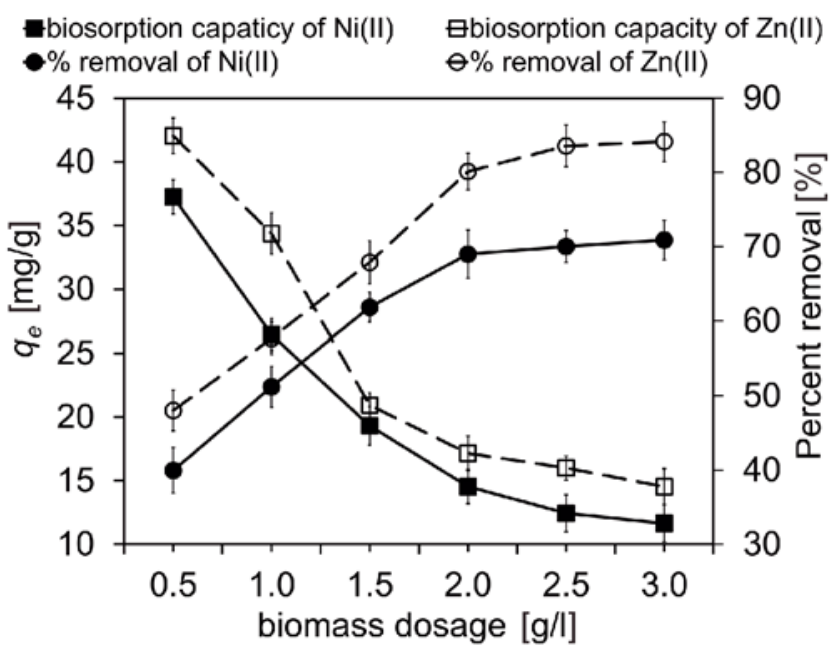

Figure 3. Effect of biomass dosage on biosorption capacity and percent removal of $\mathrm{Ni}(\mathrm{II})$ and $\mathrm{Zn}(\mathrm{II})$ by $Y$. lipolytica (metal concentration: $100 \mathrm{mg} / \mathrm{l}, \mathrm{pH}$ : 5.0-6.0, temperature: $\left.30^{\circ} \mathrm{C}\right)$.

The precentage of removal of zinc and nickel ions from the solution increased with the increase in biomass concentration, and a dose of $3.0 \mathrm{~g} / \mathrm{l}$ resulted in a $70.89 \%$ and $84.15 \%$ decrease with a simultaneous decrease of sorption capacity to 11.65 and $14.53 \mathrm{mg} / \mathrm{g}$. In turn, the sorption capacity of $Y$. lipolytica biomass decreased with increasing concentration of yeast cells. With an increase in biomass concentration the \% removal increases because more biosorbent (binding sites) are available for the same amount of cations while specific uptake of metal ions decreased due to lower metal concentration in the solution after a very fast superficial adsorption onto the microbial cells ${ }^{27}$. However, the biomass can undergo different modifications depending on the experimental conditions, such as $\mathrm{pH}$, ionic strength, temperature, metal ion in solution and its same biomass concentration level: for example, the aggregates formed during biosorption may reduce the effective biosorption are $\mathrm{a}^{11}$. In the case of biosorption of $\mathrm{Ni}$ (II) and $\mathrm{Zn}$ (II) from a solution of $100 \mathrm{mg} / \mathrm{l}$, the optimal dose of biosorbent $2 \mathrm{~g} / \mathrm{l}$, which guaranteed a high yield, respectively $68.99 \%$ and $80.12 \%$, with the sorption capacity at 14.54 and $17.15 \mathrm{mg} / \mathrm{g}$. These conclusions are confirmed by the study of $\mathrm{Li}$ et al. ${ }^{23}$.

\section{Effect of contact time and temperature}

The process of biosorption consists in the transport of nickel and zinc ions from the bulk of the solution to the surface of the sorbent. The rate of the process depends first off all on the stages of the mass transfer. The first stage is characterized by the most intense sorption, which is due to the accessibility of the free active sites on the surface of the sorbent and thereby a large concentration gradient that activates the process ${ }^{1,17,19,28}$. In the case of the Y. lipolytica biomass, the first stage of rapid transfer of metals to active sites on the biosorbent's surface lasted approx. 20 minutes. The next stage, in which equilibrium was reached, lasted about 60 minutes (Fig. 4).

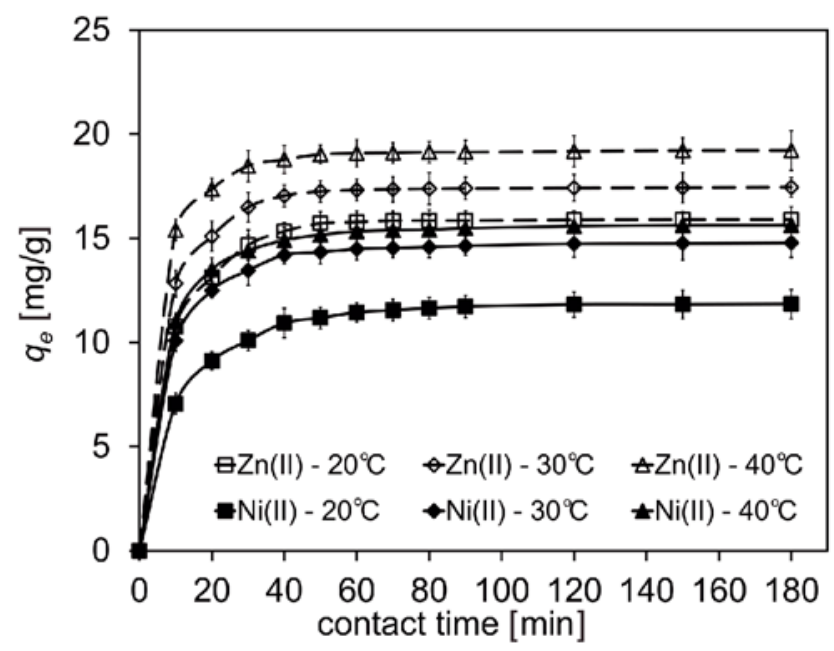

Figure 4. Effect of contact time and temperature on the biosorption of $\mathrm{Ni}(\mathrm{II})$ and $\mathrm{Zn}(\mathrm{II})$ onto $Y$. lipolytica biomass (metal concentration: $100 \mathrm{mg} / \mathrm{l}, \mathrm{pH}$ : 5.0-6.0, biomass dosage: $2 \mathrm{~g} / \mathrm{l}$ )

Therefore, this time value was selected as optimum contact time for sufficient biosorption of the metal ions. The almost same contact time was reported in several earlier works which related with the biosorption of the same metal ions on various biomasses ${ }^{20,23}$.

The rate of mass transfer depends also on the conditions under which the process occurs. Temperature is among the factors that most affect the kinetics of biosorption within the range 20 to $40^{\circ} \mathrm{C}$. An increase in temperature 
up to $40^{\circ} \mathrm{C}$ brings about an increase in the rate of biosorption and enhancement of the sorptive capacity ${ }^{29}$. At equilibrium, the maximum biosorption of $\mathrm{Ni}(\mathrm{II})$ at 20,30 and $40^{\circ} \mathrm{C}$ was $11.48,14.78$ and $15.64 \mathrm{mg} / \mathrm{g}$, respectively and for $\mathrm{Zn}(\mathrm{II})$ these were $15.90,17.45$ and $19.21 \mathrm{mg} / \mathrm{g}$. The results indicate that biosorption of $\mathrm{Ni}(\mathrm{II})$ and $\mathrm{Zn}$ (II) by the $Y$. lipolytica biomass is endothermic. The studies of many authors confirm such an effect of temperature on biosorption ${ }^{20,24,26,28,30,31}$.

\section{Biosorption kinetics}

Biosorption kinetic studies are crucial for describing the adsorbate biosorption rates and for determining the rate-determining step. The pseudo-first order, second order and intraparticle diffusion kinetic models were used in this work. The plots $\left(q_{e}-q_{t}\right)$ of vs. for the pseudo-first order model were not shown as figure because the coefficients of determination for this model at studied temperatures is low $\left(R^{2}=0.896-0.944\right.$ for the $\mathrm{Ni}(\mathrm{II})$ biosorption and $R^{2}=0.729-0.810$ for $\mathrm{Zn}(\mathrm{II})$ biosorption, as seen in Table 2). Also, the equilibrium uptake $\left(q_{e}\right)$ values calculated from the pseudo-first order kinetic model did not agree well with the experimental $\left(q_{e \text { exp }}\right)$ values. It can be concluded from the $R^{2}$ and $q_{e}$ values that the biosorption mechanisms of nickel and zinc ions onto $Y$. lipolytica biomass does not follow the pseudo-first order kinetic model.
The pseudo-second order model defines the measurements very well with the correlation coefficients very high (>0.999) (Table 2). The calculated $q_{e}$ values also agree very well with the experimental data $\left(q_{e \text { exp }}\right)$. The data presented in Table 2 indicate that the initial speed of sorption $(h)$ for $\mathrm{Ni}(\mathrm{II})$ and $\mathrm{Zn}(\mathrm{II})$ increased with an increase in temperature from 20 to $40^{\circ} \mathrm{C}$, respectively from 2.155 to $4.955 \mathrm{mg} / \mathrm{g} \cdot \mathrm{min}$ and 5.285 to $11.61 \mathrm{mg} / \mathrm{g} \cdot \mathrm{min}$. At the same time we observed an increase in the rate constant $k_{2}$, respectively, from 0.014 to $0.019 \mathrm{~g} / \mathrm{mg} \cdot \min$ and from 0.020 to $0.031 \mathrm{~g} / \mathrm{mg} \cdot \mathrm{min}$. This means that biosorption occurs more quickly at higher temperatures. Due to the temperature the molecule energy rises and so does the possibility of the molecule-absorbent reaction $^{29}$. Also the amount of nickel and zinc ions adsorbed by the yeast biomass increased when the temperature of the process increased from 20 to $40^{\circ} \mathrm{C}$, respectively, from 12.32 to $15.97 \mathrm{mg} / \mathrm{g}$ and from 16.29 to $19.46 \mathrm{mg} / \mathrm{g}$ (Table 2). However, the equilibrium sorption capacity was little affected by increased temperature. In conventional physisorption systems, increasing temperature usually increases the rate of approach to equilibrium, but decreases the equilibrium capacity ${ }^{30}$.

On the basis of these results it can be concluded that the kinetics of $\mathrm{Ni}$ (II) and $\mathrm{Zn}$ (II) biosorption by the biomass of $Y$. lipolytica proceeded in accordance with the model of the pseudo-second order. Similar conclusions

Table 2. Kinetic parameters for biosorption of Ni(II) and $\mathrm{Zn}(\mathrm{II})$ on $Y$. lipolytica biomass at different temperatures

\begin{tabular}{|c|c|c|c|c|c|c|c|c|c|}
\hline \multirow{2}{*}{$\begin{array}{l}\text { Metal } \\
\text { ion }\end{array}$} & \multirow[t]{2}{*}{ Temperature $\left[{ }^{\circ} \mathrm{C}\right]$} & \multirow{2}{*}{$\begin{array}{c}q_{e \exp } \\
{[\mathrm{mg} / \mathrm{g}]}\end{array}$} & \multicolumn{3}{|c|}{ Pseudo-first-order } & \multicolumn{4}{|c|}{ Pseudo-second-order } \\
\hline & & & $k_{1}[1 / \mathrm{min}]$ & $q_{e}[\mathrm{mg} / \mathrm{g}]$ & $R^{2}$ & $\begin{array}{c}k_{2} \\
{[\mathrm{~g} / \mathrm{mg} \cdot \mathrm{min}]}\end{array}$ & $q_{\mathrm{e}}[\mathrm{mg} / \mathrm{g}]$ & $\begin{array}{c}h \\
{[\mathrm{mg} / \mathrm{g} \cdot \min ]}\end{array}$ & $R^{2}$ \\
\hline \multirow[t]{3}{*}{$\mathrm{Ni}(\mathrm{II})$} & 20 & 11.90 & 0.060 & 3.079 & 0.896 & 0.014 & 12.32 & 2.155 & 0.999 \\
\hline & 30 & 14.80 & 0.069 & 2.901 & 0.944 & 0.019 & 15.13 & 4.380 & 0.999 \\
\hline & 40 & 15.70 & 0.055 & 2.476 & 0.898 & 0.019 & 15.97 & 4.955 & 1.000 \\
\hline \multirow[t]{3}{*}{$\mathrm{Zn}(\mathrm{II})$} & 20 & 15.95 & 0.059 & 1.792 & 0.729 & 0.020 & 16.29 & 5.285 & 0.999 \\
\hline & 30 & 17.50 & 0.055 & 1.592 & 0.746 & 0.024 & 17.76 & 7.728 & 0.999 \\
\hline & 40 & 19.25 & 0.058 & 1.488 & 0.810 & 0.031 & 19.46 & 11.61 & 1.000 \\
\hline
\end{tabular}

The straight lines obtained from the plot of versus showed good fit of experimental data with the second-order kinetic model for the different temperatures $\left(20-40^{\circ} \mathrm{C}\right)$ (Fig. 5).

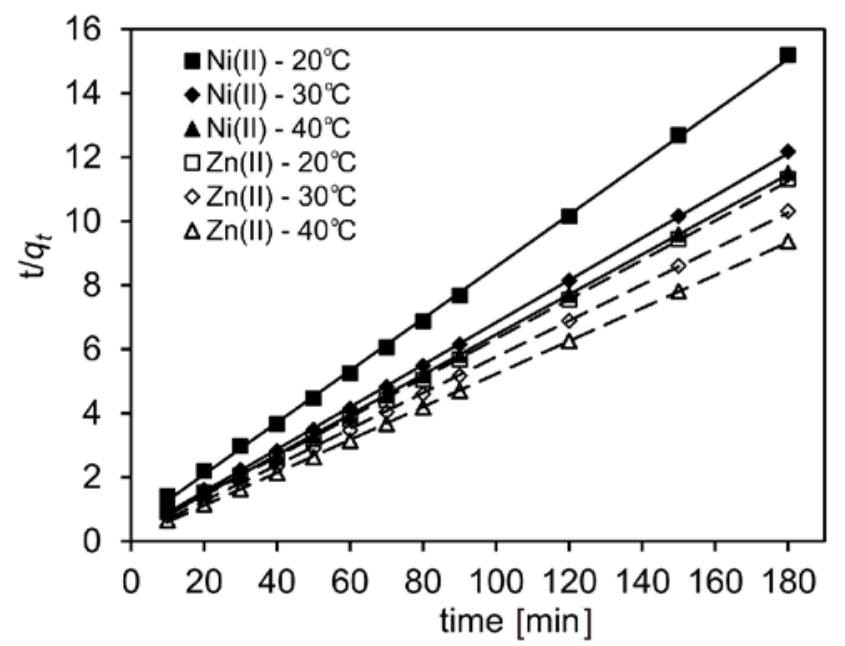

Figure 5. Pseudo-second order kinetic of $\mathrm{Ni}(\mathrm{II})$ and $\mathrm{Zn}(\mathrm{II})$ biosorption by $Y$. lipolytica biomass at different temperatures (metal concentration: $100 \mathrm{mg} / \mathrm{l}, \mathrm{pH}$ : 5.0-6.0, biomass dosage $2 \mathrm{~g} / \mathrm{l}$ ) about the kinetics of nickel and zinc biosorption are also presented by Asfaram et al. ${ }^{19}$ using Y. lipolytica ISF7 biomass, by Suazo-Madrid et al. ${ }^{31}$ who used the yeast Rhodotorula glutinis as biosorbent, and by Farhan and Khadom $^{\mathbf{3 2}}$ using Saccharomyces cerevisiae.

The energy of activation $\left(E_{A}\right)$ was determined from the slope of the Arrhenius plot of $\ln k_{2}$ versus $1 / T$ according to Eq. (6) to be 11.77 and $16.67 \mathrm{~kJ} / \mathrm{mol}$ for $\mathrm{Ni}(\mathrm{II})$ and $\mathrm{Zn}$ (II) respectively (Table 5). These results suggest that biosorption of nickel and zinc ions by the yeast biomass is a process of chemical adsorption. Shinde et al. ${ }^{3}$ and Baysal et al. $^{28}$ report that the activation energy for the chemical adsorption is usually greater than $4-6 \mathrm{~kJ} / \mathrm{mol}$. Positive values of activation energy $\left(E_{A}\right)$ confirm the earlier conclusion that higher temperatures promote the biosorption of nickel and zinc ions by Y. lipolytica biomass and the process is endothermic. Equally low results were obtained by Horsfall and Spiff ${ }^{\mathbf{3 3}}$ and Uslu and Tanyol ${ }^{\mathbf{3 4}}$.

The process of sorption falls into three basic stages: (1) diffusive mass transfer of the component from the bulk through the boundary layer close to the surface of the sorbent, (2) intraparticle diffusion in the pores of the sorbent, (3) binding of the molecules to the active sites in the pores of the sorbent. The binding of the 
molecules to the active sites is the fastest stage. It is assumed that this stage does not limit a mass transfer ${ }^{29}$.

The Weber-Morris model assumes three stages: external mass transfer and two stages of intraparticle diffusion in the larger and smaller pores until saturation of the surface. The Weber-Morris plot for adsorption $\mathrm{Ni}(\mathrm{II})$ and $\mathrm{Zn}(\mathrm{II})$ is given in Figure 6. If the intraparticle diffusion is the sole rate determining step, the plots of should be linear and pass through the origin. Non-linearity indicates that intraparticle diffusion is not the only rate-limiting step in the adsorption process. The graph of dependencies $q_{t}$ from $t^{0.5}$ ought to contain the dependency lines. The first linear dependency corresponds to the external surface uptake, the other linear dependency relates to the gradual uptake reflecting intraparticle diffusion as the rate limiting step, whereas the third constitutes a stage during which equilibrium is being attained, when the molecules take up their positions within the pores of the sorbent, the diffusion slows down because of the concentration gradient that decreases with time.

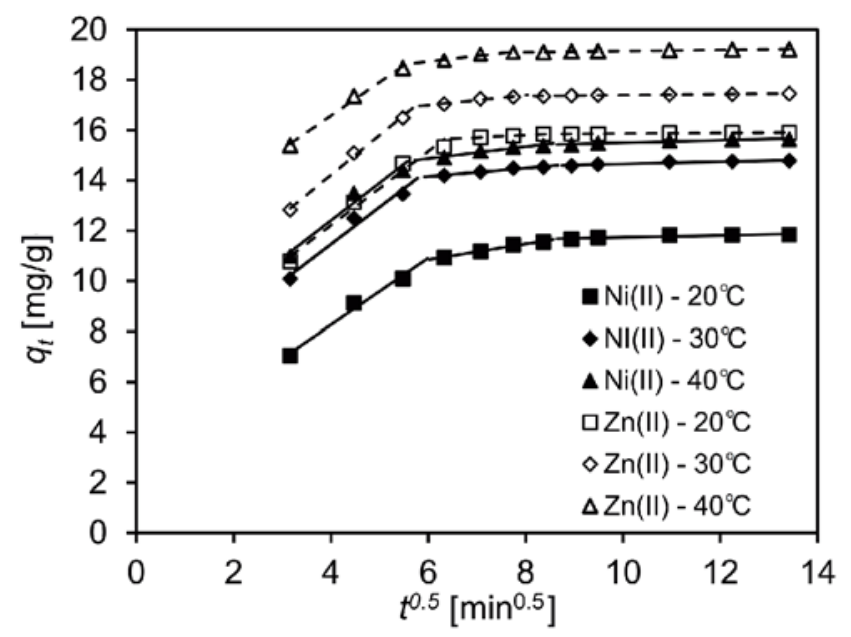

Figure 6. Weber-Morris plots for the biosorption of $\mathrm{Ni}(\mathrm{II})$ and $\mathrm{Zn}(\mathrm{II})$ by Y. lipolytica biomass at different temperatures (metal concentration: $100 \mathrm{mg} / \mathrm{l}, \mathrm{pH}$ : 5.0-6.0, biomass dosage $2 \mathrm{~g} / \mathrm{l}$ )

A high value of intercept may imply that the boundary layer significantly affects mass transfer within the sorbent (Table 3). The intercept levels were lowest for the first linear range (2.967-11.23 mg/g), which may mean that this stage takes place quickly and partially inhibits the transfer of mass. The same values are much higher for the other two stages, and in particular for the third stage $(11.33-18.93 \mathrm{mg} / \mathrm{g})$. That intercept increases slightly with the increase in temperature for the individual stages of adsorption. The kinetic parameter decreases in particular stages, which confirms the assumption that it is the stage of penetration of the mass in the boundary layer that occurs with the largest rate, then comes diffusion in the pores, and the stage of attaining equilibrium is slowest. Analogous conclusions are presented by Asfaram et al. ${ }^{19}$, Munagapati et al. $^{25}$ and Witek-Krowiak ${ }^{29}$.

\section{Biosorption isotherm models}

One of the important aspects for evaluation of the sorption process as a unit operation is the equilibria of sorption. Figure 7 shows the Langmuir plots at different temperature and the constants $q_{\max }$ and $K_{L}$ are tabulated in Table 4.

Another essential parameter of the Langmuir isotherm is $R_{L}$. It is reported ( $\mathrm{Lin}$ et al. ${ }^{\mathbf{1 6}}$ ) that $R_{L}$ indicates the shape of the isotherm and nature of the biosorption process $\left(R_{L}>1\right.$ : unfavorable; $=1$ : linear; $0<R_{L}<1$ : favorable; $R_{L}=0$ : irreversible). The $R_{L}$ values obtained from this study were $0.140-0.170$ to $\mathrm{Ni}(\mathrm{II})$ adsorption and $0.155-0.174$ to $\mathrm{Zn}$ (II) adsorption (Table 4).

Figure 8 shows the Freundlich plots at different temperatures and the constants and are tabulated in Table 4.

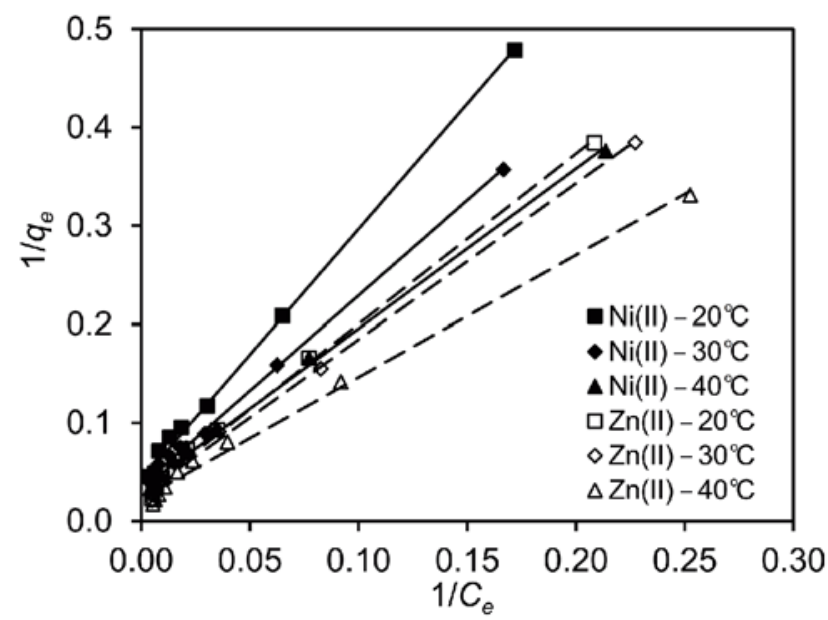

Figure 7. Langmuir isotherm plots for the biosorption of $\mathrm{Ni}(\mathrm{II})$ and $\mathrm{Zn}$ (II) by Y. lipolytica biomass at different temperatures (metal concentration: $100 \mathrm{mg} / \mathrm{l}, \mathrm{pH}$ : 5.0-6.0, biomass dosage $2 \mathrm{~g} / \mathrm{l}$ )

As shown in Table 4, experimental data on the isotherms at 20,30 and $40^{\circ} \mathrm{C}$ were better fitted to the Langmuir model $\left(R^{2}>0.994\right)$ than to the Freundlich model $\left(R^{2}<0.993\right)$, suggesting that the former better describes the state of equilibrium of $\mathrm{Ni}$ (II) and $\mathrm{Zn}(\mathrm{II})$ biosorption by the yeast biomass under the experimental conditions. The maximum sorption capacity of the monolayer increased with increasing temperature $\left(20-40^{\circ} \mathrm{C}\right)$

Table 3. Kinetic parameters of Weber-Morris model

\begin{tabular}{|c|c|c|c|c|c|c|c|c|c|c|}
\hline \multirow{2}{*}{$\begin{array}{l}\text { Metal } \\
\text { ion }\end{array}$} & \multirow{2}{*}{$\begin{array}{c}\text { Temperature } \\
{\left[{ }^{\circ} \mathrm{C}\right]}\end{array}$} & \multicolumn{3}{|c|}{ First linear portion } & \multicolumn{3}{|c|}{ Second linear portion } & \multicolumn{3}{|c|}{ Third linear portion } \\
\hline & & $\begin{array}{c}k_{i d} \\
{\left[\mathrm{mg} / \mathrm{g} \cdot \min ^{0.5}\right]}\end{array}$ & $\begin{array}{c}C_{i d} \\
{[\mathrm{mg} / \mathrm{g}]}\end{array}$ & $R^{2}$ & $\begin{array}{c}k_{i d} \\
{\left[\mathrm{mg} / \mathrm{g} \cdot \min ^{0.5}\right]}\end{array}$ & $\begin{array}{c}C_{i d} \\
{[\mathrm{mg} / \mathrm{g}]}\end{array}$ & $R^{2}$ & $\begin{array}{c}k_{\text {id }} \\
{\left[\mathrm{mg} / \mathrm{g} \cdot \mathrm{min}^{0.5}\right]}\end{array}$ & $\begin{array}{c}C_{i d} \\
{[\mathrm{mg} / \mathrm{g}]}\end{array}$ & $R^{2}$ \\
\hline \multirow{3}{*}{$\mathrm{Ni}(\mathrm{II})$} & 20 & 1.324 & 2.967 & 0.984 & 0.313 & 8.969 & 0.982 & 0.039 & 11.33 & 0.809 \\
\hline & 30 & 1.477 & 5.553 & 0.972 & 0.169 & 13.14 & 0.970 & 0.044 & 14.21 & 0.893 \\
\hline & 40 & 1.495 & 6.425 & 0.965 & 0.237 & 13.44 & 0.946 & 0.050 & 14.99 & 0.903 \\
\hline & & & & & & & & & & \\
\hline \multirow{3}{*}{$\mathrm{Zn}(\mathrm{II})$} & 20 & 1.472 & 6.327 & 0.979 & 0.097 & 15.03 & 0.999 & 0.011 & 15.74 & 0.879 \\
\hline & 30 & 1.588 & 7.862 & 0.996 & 0.198 & 15.80 & 0.938 & 0.017 & 17.22 & 0.910 \\
\hline & 40 & 1.335 & 11.23 & 0.993 & 0.219 & 17.42 & 0.907 & 0.021 & 18.93 & 0.947 \\
\hline
\end{tabular}


Table 4. Langmuir and Freundlich isotherm constants and correlation coefficients for the biosorption of Ni(II) and Zn(II) by Y. lipolytica biomass at different temperatures

\begin{tabular}{|l|c|c|c|c|c|c|c|c|}
\hline \multirow{2}{*}{ Metal ion } & \multirow{2}{*}{ Temperature $\left[{ }^{\circ} \mathrm{C}\right]$} & \multicolumn{3}{|c|}{ Langmuir } & \multicolumn{3}{|c|}{ Freundlich } \\
\cline { 2 - 8 } & & $q_{\max }[\mathrm{mg} / \mathrm{g}]$ & $K_{L}[\mathrm{l} / \mathrm{mg}]$ & $R_{L}$ & $R^{2}$ & $K_{F}[/ / \mathrm{mg}]$ & $1 / n$ & $R^{2}$ \\
\hline \multirow{3}{*}{$\mathrm{Ni}(\mathrm{II})$} & 20 & 24.10 & 0.017 & 0.170 & 0.997 & 1.200 & 0.614 & 0.976 \\
\cline { 2 - 8 } & 30 & 27.85 & 0.019 & 0.152 & 0.997 & 1.222 & 0.570 & 0.966 \\
\hline & 40 & 30.12 & 0.020 & 0.140 & 0.996 & 1.165 & 0.619 & 0.989 \\
\hline \multirow{3}{*}{$\mathrm{Zn}(\mathrm{II})$} & & & & & & & & \\
& 20 & 36.50 & 0.016 & 0.174 & 0.996 & 1.067 & 0.696 & 0.993 \\
\cline { 2 - 8 } & 30 & 38.17 & 0.017 & 0.168 & 0.995 & 1.011 & 0.701 & 0.989 \\
\cline { 2 - 8 } & 40 & 44.44 & 0.018 & 0.155 & 0.994 & 1.137 & 0.727 & 0.993 \\
\hline
\end{tabular}

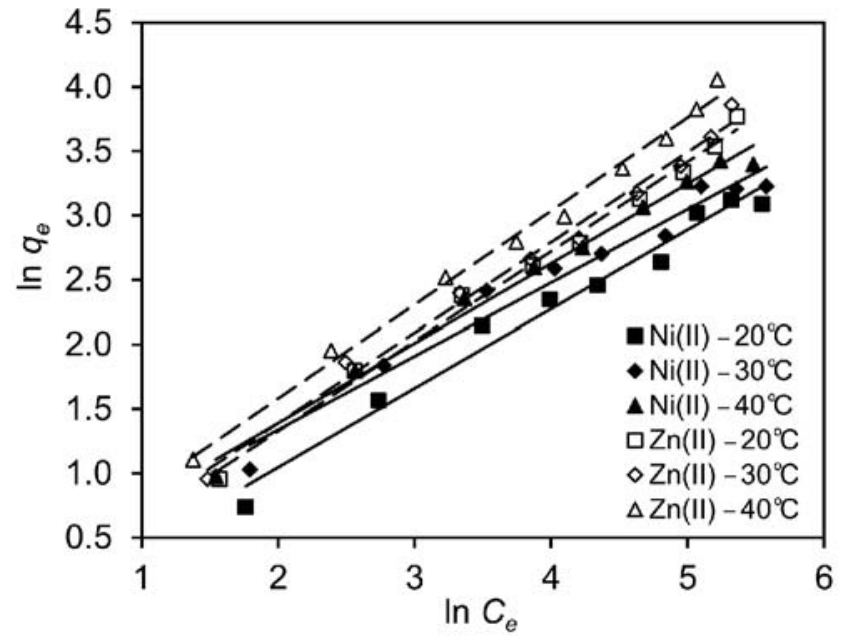

Figure 8. Freundlich isotherm plots for the biosorption of $\mathrm{Ni}(\mathrm{II})$ and $\mathrm{Zn}(\mathrm{II})$ by Y. lipolytica biomass at different temperatures (metal concentration: $100 \mathrm{mg} / \mathrm{l}, \mathrm{pH}$ : 5.0-6.0, biomass dosage $2 \mathrm{~g} / \mathrm{l}$ )

from 24.10 to $30.12 \mathrm{mg} / \mathrm{g}$ and from 36.50 to $44.44 \mathrm{mg} / \mathrm{g}$, for nickel and zinc ions, respectively. Similar results of biosorption were obtained by Asfaram et al. ${ }^{19}$, Özer and Özer ${ }^{22}$, Pahlavanzadeh et al. ${ }^{24}$, and Chen et al. ${ }^{35}$ and Nasernejad et al. ${ }^{36}$, using Y. lipolytica ISF7, Saccharomyces cerevisiae, brown alge Padina australis, bacteria Pseudomonas putida, and carrot residues as biosorbents, respectively. A much lower maximum sorption capacity was observed by Sari et al..$^{20}$ and Celaya et al..$^{37}$ who used Cladonia furcata and Thiobacillus ferrooxidans; the corresponding values were $7.9 \mathrm{mg} / \mathrm{g}$ (nickel) and $9.7 \mathrm{mg} / \mathrm{g}$ (zinc). On the other hand, a higher biosorption of $\mathrm{Ni}(\mathrm{II})$ was observed by Shinde et al. ${ }^{3}$ and Suazo-Madrid et al. ${ }^{31}$, at 48.3 and $112.9 \mathrm{mg} / \mathrm{g}$, respectively, using Y. lipolytica and Rhodotorula glutinis as biosorbents. In the case of $\mathrm{Zn}(\mathrm{II})$ biosorption, the maximum sorption capacity obtained in the studies by Joo et al. ${ }^{1}$ and $\mathrm{Li}$ et al. ${ }^{23}$ were 83.3 and $75.8 \mathrm{mg} / \mathrm{g}$, respectively, using Pseudomonas aeruginosa and Streptomyces ciscaucasicus, respectively.

The constant $K_{L}$ changed in a similar fashion. Its slightly higher values for the biosorption of $\mathrm{Ni}(\mathrm{II})$ indicate a higher affinity of biomass for the sorption of these ions, which increased with increasing temperature. The magnitude of $K_{F}$ and $n$ constants indicated that $Y$. lipolytica had a high adsorption capacity for $\mathrm{Ni}(\mathrm{II})$ and $\mathrm{Zn}(\mathrm{II})$ ions. Besides, $\frac{1}{n}$ that values of between 0.1 and 1.0 indicate suitable nickel and zinc ions adsorption on anion exchange ${ }^{11}$.

\section{Thermodynamic parameters}

In this study, the thermodynamic parameters have been calculated using the Langmuir isotherm, i.e. by replacing the equilibrium constant, $K_{c}^{o}$ from Eqs. (12) and (14) by the Langmuir isotherm constant $K_{L}$, and are given in Table 4. The values of $\Delta H^{o}$ and $\Delta S^{o}$ were calculated from the slope and intercept of the plots of $\ln K_{c}^{o}$ versus $1 / T$ (Fig. 9) ${ }^{30}$.

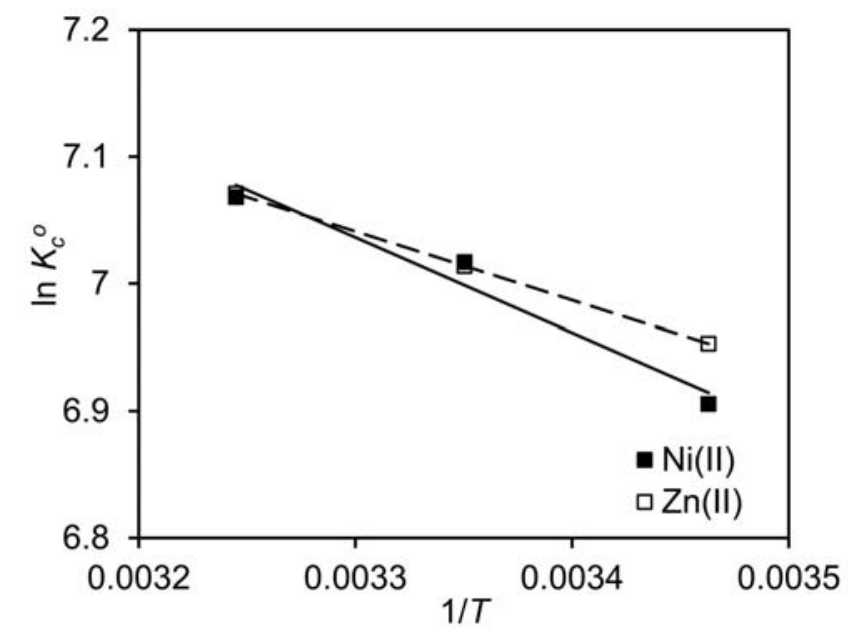

Figure 9. Plot of $\ln K_{c}^{o}$ vs. 1/T for the biosorption of $\mathrm{Ni}(\mathrm{II})$ and $\mathrm{Zn}(\mathrm{II})$ by $Y$. lipolytica biomass

The thermodynamic treatment of the sorption data indicates that $\Delta G^{o}$ values were negative at all the temperatures investigated. The negative values of $\Delta G^{o}$ (Table 5) indicate the spontaneous nature of adsorption of metal ion by the biomass and the likelihood of increased spontaneity of the process induced by increased temperature. It is of note that $\Delta G^{o}$ up to $-20 \mathrm{~kJ} / \mathrm{mol}$ are consistent with electrostatic interaction between sorption sites and the metal ion (physical adsorption) while $\Delta G^{o}$ values more negative than $-40 \mathrm{~kJ} / \mathrm{mol}$ involve charge sharing or transfer from the biomass surface to the metal ion to form a coordinate bond (chemical adsorption) ${ }^{33}$. The $\Delta G^{o}$ values obtained in this study for both metal

Table 5. Values of thermodynamic parameters for the biosorption of $\mathrm{Ni}(\mathrm{II})$ and $\mathrm{Zn}(\mathrm{II})$ by $Y$. lipolytica biomass

\begin{tabular}{|c|c|c|c|c|c|c|c|c|}
\hline \multirow[b]{2}{*}{ Temperature $\left[{ }^{\circ} \mathrm{C}\right]$} & \multicolumn{4}{|c|}{$\mathrm{Ni}(\mathrm{II})$} & \multicolumn{4}{|c|}{$\mathrm{Zn}(\mathrm{II})$} \\
\hline & $\Delta G^{\circ}[\mathrm{kJ} / \mathrm{mol}]$ & $E_{A}[\mathrm{~kJ} / \mathrm{mol}]$ & $\Delta S^{o}[\mathrm{~kJ} / \mathrm{mol} \cdot \mathrm{K}]$ & $\Delta H^{\circ}[\mathrm{kJ} / \mathrm{mol}]$ & $\begin{array}{c}\Delta G^{\circ} \\
{[\mathrm{kJ} / \mathrm{mol}]}\end{array}$ & $\begin{array}{c}E_{A} \\
{[\mathrm{~kJ} / \mathrm{mol}]}\end{array}$ & $\Delta S^{\circ}[\mathrm{kJ} / \mathrm{mol} \cdot \mathrm{K}]$ & $\Delta H^{\circ}[\mathrm{kJ} / \mathrm{mol}]$ \\
\hline 20 & -16.82 & \multirow{3}{*}{11.77} & \multirow{3}{*}{0.079} & \multirow{3}{*}{6.219} & -16.94 & \multirow{3}{*}{16.67} & \multirow{3}{*}{0.073} & \multirow{3}{*}{4.490} \\
\hline 30 & -17.68 & & & & -17.67 & & & \\
\hline 40 & -18.39 & & & & -18.40 & & & \\
\hline
\end{tabular}


ions are $<-20 \mathrm{~kJ} / \mathrm{mol}$, indicative that physical adsorption is the predominant mechanism in the sorption process. Asfaram et al. ${ }^{19}$ show an analogous mechanism of biosorption of $\mathrm{Ni}(\mathrm{II}), \mathrm{Zn}(\mathrm{II})$ and $\mathrm{Co}(\mathrm{II})$ ions using $Y$. lipolytica ISF7 in their study. The positive values $\Delta H^{\circ}$ (Table 5) of suggests the endothermic nature of $\mathrm{Ni}(\mathrm{II})$ and $\mathrm{Zn}$ (II) biosorption. The positive values of $\Delta S^{o}$ show that the freedom of metal ions is not too restricted in the biomass confirming a physical adsorption, which is further confirmed by the relatively low values of $\Delta G^{o}$.

\section{CONCLUSIONS}

The obtained results indicate that the optimum parameters of nickel and zinc ion biosorption by the dead biomass of Yarrowia lipolytica yeast were as follows: $\mathrm{pH}$ at 6.0 and 5.0, and the use of biosorbent at a dose of 2 $\mathrm{g} / \mathrm{l}$. Most of the metal ions were adsorbed in the first 20 minutes, and equilibrium was established after 60 minutes. The kinetics of biosorption proceeded in accordance with the pseudo-second order model, suggesting chemisorption in binding the metal ions by the yeast. The good fit of the Weber-Morris model to the experimental data indicates that intraparticle diffusion was not the only limiting stage during biosorption. Increasing the temperature from 20 to $40^{\circ} \mathrm{C}$ increased the sorption capacity of the biomass, and increased the rate constants. The activation energy values $(11.77$ and $16.67 \mathrm{~kJ} / \mathrm{mol})$ calculated on the basis of kinetic models also suggest the chemical character of the adsorption process. The analysis of the kinetic results revealed that the binding of $\mathrm{Ni}(\mathrm{II})$ and $\mathrm{Zn}(\mathrm{II})$ ions is a complex and multistage process. The mechanism of biosorption includes both intraparticle diffusion and chemical reactions. The equilibrium of nickel and zinc ion sorption by Y. lipolytica was very well described by the Langmuir model $\left(R^{2}>0.994\right)$, and the maximum sorption capacity at $40^{\circ} \mathrm{C}$ amounted to 30.12 and $44.44 \mathrm{mg} / \mathrm{g}$. FTIR analysis of yeast biomass confirmed the participation of hydroxy, carboxyl, amide and amine groups in the biosorption process, and potential involvement of complexation in the mechanism of binding nickel and zinc. The determined thermodynamic parameters indicate a spontaneous and endothermic nature of the process. Energy $\Delta G^{o}$ values of less than $-20 \mathrm{~kJ} / \mathrm{mol}$ indicate the involvement of physical adsorption in the biosorption of $\mathrm{Ni}(\mathrm{II})$ and $\mathrm{Zn}(\mathrm{II})$ by the biomass of $Y$. lipolytica. The obtained results confirm the usefulness of the $Y$. lipolytica biomass in the process of zinc and nickel ion biosorption from aqueous solutions. Taking into account the economic and ecological aspects, it seem preferable to use waste biomass obtained during the production of organic acids, sweeteners, or flavor compounds.

\section{LITERATURE CITED}

1. Joo, J.H., Hassan, S.H.A. \& Oh, S.E. (2010). Comparative study of biosorption of $\mathrm{Zn}^{2+}$ by Pseudomonas aeruginosa and Bacillus cereus. Int. Biodeter. Biodegr. 64, 734-741. DOI: 10.1016/j.ibiod.2010.08.007.

2. Mudhoo, A., Garg, V.K. \& Wang, S. (2012). Heavy Metals: Toxity and Removal by Biosorption. Lichtfouse, E., Schwarzbauer, J. \& Robert, D. (Eds.), Environmental Chemistry for a Sustainable World: Volume 2: Remediation of Air and Water Pollution (pp. 379-442). Springer Science+Business Media B.V.
3. Shinde, N.R., Bankar, A.V., Kumar, A.R. \& Zinjarde, A.A. (2012). Removal of Ni (II) ions from aqueous solutions by biosorption onto two strains of Yarrowia lipolytica. J. Environ. Manag. 102, 115-124. DOI: 10.1016/j.jenvman.2012.02.026.

4. Gavrilescu, M. (2010). Biosorption in Environmental Remediation. Fulekar, M.H. (Eds.) Bioremed. Technol.: Rec. Adv. (pp. 35-99). Capital Publishing Company. DOI: 10.1007/97890-481-3678-0_1.

5. Wang, J. \& Chen, C. (2009). Biosorbents for heavy metals removal and their future. Biotechnol. Adv. 27, 195-226. DOI: 10.1016/j.biotechadv.2008.11.002.

6. Beopoulos, A., Chardot, T. \& Nicaud, J.M. (2009). Yarrowia lipolytica: A model and a tool to understand the mechanisms implicated in lipid accumulation. Biochimie 91, 692-696. DOI: 10.1016/j.biochi.2009.02.004.

7. Bankar, A.V., Kumar, A.R. \& Zinjarde, S.S. (2009). Environmental and industrial applications of Yarrowia lipolytica. Appl. Microbiol. Biotechnol. 84, 847-865. DOI: 10.1007/ s00253-009-2156-8.

8. Lanciotti, R., Gianotti, A., Baldi, D., Angrisani, R., Suzzi, G., Mastrocola, D. \& Guerzoni, M.E. (2005). Use of Yarrowia lipolytica strains for the treatment of olive mill wastewater. Biores. Technol. 96, 317-322. DOI: 10.1016/j.biortech.2004.04.009. 9. Lagergren, S. (1898). Zur theorie der sogenannten adsorptiong gelöster stoffe. Kungliga Svenska Vetenskapsakad. Stockholm: Handlingar. Bihang. 24(4), 1-39.

10. Ho, Y.S. \& McKay, G. (1999). Pseudo-second order model for sorption processes. Process. Biochem. 34(5), 451-465.

11. Ertugay, N. \& Bayhan, T.K. (2008). Biosorption of Cr(VI) from aqueous solution by biomass of Agaricus bisporus. J. Hazard. Mater. 154, 432-439. DOI: 10.1016/j.jhazmat.2007.10.070. 12. Weber, W.J. \& Morris, J.C. (1963). Intraparticle diffusion during the sorption of surfactants onto activated carbon. $J$. Sanit Eng. Div. Am. Soc. Civ. Eng. 89, 53-61.

13. Blázquez, G., Martín-Lara, M.A., Tenorio, G. \& Calero, M. (2011). Batch biosorption of lead(II) from aqueous solutions by olive tree pruning waste: Equilibrium, kinetics and termodynamic study. Chem. Eng. J. 168, 170-177. DOI: 10.1016/j. cej.2010.12.059.

14. Langmuir, I. (1918). The adsorption of gases on plane surfaces of glass, mica and platinum. J. Am. Chem. Soc. 40(9), 1361-1403. DOI: 10.1021/ja02242a004.

15. Freundlich, H.M.F. (1906). Uber Die Adsorption in Losungen. Zeitschrift For Physikalische Chemie 57A, 385-470.

16. Lin, Y., Wang, X., Wang, B., Mohamad, O. \& Wei, G. (2012). Bioaccumulation characterization of zinc and cadmium by Streptomyces zinciresistens, a novel actinomycete. Ecotox. Environ. Safe. 77, 7-17. DOI: 10.1016/j.ecoenv.2011.09.016.

17. Yin, H., He, B., Peng, H., Ye, J., Yang, F. \& Zhang, N. (2008). Removal of $\mathrm{Cr}(\mathrm{VI})$ and $\mathrm{Ni}(\mathrm{II})$ from aqueous solution by fused yeast: Study of cations release and biosorption mechanism. J. Hazard. Mater. 158, 568-576. DOI: 10.1016/j. hazmat.2008.01.113.

18. Ahmad, M.F., Haydar, S. \& Quraishi, A. (2013). Enhancement of biosorption of zinc ions from aqueous solution by immobilized Candida utilis and Candida tropicalis cells. Int. Biodeter. Biodegr. 83, 119-128. DOI: 10.1016/j.ibiod.2013.04.016. 19. Asfaram, A., Ghaedi, M. \& Ghezelbash, G.R. (2016). Biosorption of $\mathrm{Zn}^{2+}, \mathrm{Ni}^{2+}$ and $\mathrm{Co}^{2+}$ from water samples onto Yarowia lipolytica ISF7 using a response Surface mathodology, and analyzed by inductively coupled plasma optical emission spectrometry (ICP-OES). RSC $A d v$. 6, 23599-23610. DOI: 10.1039/c5ra27170c.

20. Sari, A., Tuzen, M., Uluözlü, Ö.D. \& Soylak, M. (2007). Biosorption of $\mathrm{Pb}(\mathrm{II})$ and $\mathrm{Ni}(\mathrm{II})$ from aqueous solution by lichen (Cladonia furcata) biomass. Biochem. Eng. J. 37, 151-158. DOI: 10.1016/j.bej.2007.04.007.

21. Liu, Y., Cao, Q., Luo, F. \& Chen, J. (2009). Biosorption of $\mathrm{Cd}^{2+}, \mathrm{Cu}^{2+}, \mathrm{Ni}^{2+}$ and $\mathrm{Zn}^{2+}$ ions from aqueous solutions 
by pretreated biomass of brown alge. J. Hazard. Mater. 163, 931-938. DOI: 10.1016/j.jhazmat.2008.07.046.

22. Özer, A. \& Özer, D. (2003). Comparative study of the biosorption of $\mathrm{Pb}(\mathrm{II}), \mathrm{Ni}(\mathrm{II})$ and $\mathrm{Cr}(\mathrm{VI})$ ions onto $S$. cerevisiae: determination of biosorption heats. J. Hazard. Mater. B100, 219-229. DOI: 10.1016/S0304-3894(03)00109-2.

23. Li, H., Lin, Y., Guan, W., Chang, J., Xu, L., Guo, J. \& Wei, G. (2010). Biosorption of $\mathrm{Zn}$ (II) by loive and dead cells of Streptomyces ciscaucasicus strain CCNWHX 72-14. J. Hazard. Mater. 179, 151-159. DOI: 10.1016/j.hazmat.2010.02.072. 24. Pahlavanzadeh, H., Keshtkar, A.R., Safdari, J. \& Abadi, Z. (2010). Biosorption of nickel(II) from aqueous solution by brown alge: Equilibrium, dynamic and thermodynamic studies. J. Hazard. Mater. 175, 304-310. DOI: 10.1016/j.jhazmat.2009.10.004.

25. Munagapati, V.S., Yarramuthi, V., Nadavala, S.K., Alla, S.R. \& Abburi, K. (2010). Biosorption of $\mathrm{Cu}(\mathrm{II}), \mathrm{Cd}(\mathrm{II})$ and $\mathrm{Pb}(\mathrm{II})$ by Acacia leucocephala bark powder: Kinetics, equilibrium and thermodynamics. Chem. Eng. J. 157, 357-365. DOI: 10.1016/j. cej.2009.11.015.

26. Subbaiah, M.V. \& Yun, Y.S. (2013). Biosorption of Nicke1(II) from Aqueous Solution by the Fungal Mat of Trametes versicolor (Rainbow) Biomass: Equilibrium, Kinetics, and Thermodynamic Studies. Biotechnol. Bioproc. E. 18, 280-288. DOI: 10.1007/s12257-012-0401-y.

27. Akhtar, K., Akhtar, M.W. \& Khalid, A.M. (2008). Removal and recovery of zirconium from its aqueous solution by Candida tropicalis. J. Hazard. Mater. 156, 108-117. DOI: 10.1016/j. jhazmat.2007.12.002.

28. Baysal, Z., Çinar, E., Bulut, Y., Alkan, H. \& Dogru, M. (2009). Equilibrum and thermodynamic studies on biosorption of $\mathrm{Pb}(\mathrm{II})$ onto Candida ablicans biomass. J. Hazard. Mater. 161, 62-67. DOI: 10.1016/j.hazmat.2008,02,122.

29. Witek-Krowiak, A. (2012). Analysis of temperature-dependent biosorption of $\mathrm{Cu}^{2+}$ ions on sunflower hulls: Kinetics, equilibrium and mechanizm of the proces. Chem. Eng. J. 192, 13-20. DOI: 10.1016/j.cej.2012.03.075.

30. Bueno, B.Y.M., Torem, M.L., Carvalho, R.J., Pino, G.A.H. \& Mesquita, L.M.S. (2011). Fundamental aspects of biosorption of lead (II) ions onto a Rhodococcus oparus strain for environmental applications. Miner. Eng. 24, 1619-1624. DOI: 10.1016/j.mineng.2011.08.018.

31. Suazo-Madrid, A., Morales-Barrera, L., Aranda-García, E. \& Cristiani-Urbina, E. (2011). Nickel(II) biosorption by Rhodotorula glutinis. J. Ind. Microbiol. Biot. 38, 51-64. DOI: 10.1007/s.10295-010-0828-0.

32. Farhan, S.N. \& Khadom, A.A. (2015). Biosorption of heavy metals from aqueous solutions by Saccharomyces cerevisiae. Int. J. Ind. Chem. 6, 119-130. DOI: 10.1007/s40090-015-0038-8. 33. Horsfall, M. \& Spiff, A.I. (2005). Effects of temperature on the sorption of $\mathrm{Pb}^{2+}$ and $\mathrm{Cd}^{2+}$ grom aqueous solution by Caladium bicolor (Wild cocoyam) biomass. Electron. J. Biotech. 8(2), 162-169. DOI: 10.2225/vol8-issue2-fulltext-4.

34. Usul, G. \& Tanyol, M. (2006). Equilibrium and thermodynamic parameters of single and binary mixture biosorption of lead (II) and copper (II) ions onto Pseudomonas putida: Effect of temperature. J. Hazard. Mater. B135, 87-93. DOI: 10.1016/j.jhazmat.2005.11.029.

35. Chen, X.C., Wang, Y.P., Lin, Q., Shi, J.Y., Wu, W.X. \& Chen, Y.X. (2005). Biosorption of copper(II) and zinc(II) from aqueous solution by Pseudomonas putida CZ1. Colloid Surf. B. 46, 101-107. DOI: 10.1016/j.colsurfb.2005.10.003.

36. Nasernejad, B., Zadeh, T.E., pour, B.B., Bygi, M.E. \& Zamani, A. (2005). Camparison for biosorption modeling of heavy metals ( $\mathrm{Cr}(\mathrm{III}), \mathrm{Cu}(\mathrm{II}), \mathrm{Zn}(\mathrm{II})$ ) adsorption from wastewater by carrot residues. Proces Biochem. 40, 1319-1322. DOI: 10.1016/j.procbio.2004.06.010.

37. Celaya, R.J., Noriega, J.A., Yeomans, J.H., Ortega, L.J. \& Ruiz-Manriquez, A. (2000). Biosorption of Zn(II) by Thioba- cillus ferrooxidans. Bioprocess. Eng. 22, 539-542. DOI: 10.1007/ s004499900106. 